\title{
Turkey's Response to Sex Trafficking of Migrant Women: Is It Efficient Enough?
}

\author{
Tatiana Zhidkova* and Oguzhan Omer Demir**
}

\begin{abstract}
Human trafficking for sexual exploitation is a serious problem affecting especially women and children. Turkey has been particularly affected by sex trafficking because of the large numbers of female migrants that it receives. This article aims to critically assess the effectiveness of Turkey's current policies against sex trafficking using a feminist theoretical perspective with a particular focus on migrant women. To this end, the scope of the problem in Turkey, the supply and demand sides of sex trafficking, and the existing policies are discussed. Sex trafficking is examined at the intersection of Turkey's migration and prostitution regimes. It is argued that Turkey's response to sex trafficking has been inefficient because it currently focuses only on the economic supply side of the problem, ignoring the patriarchal demand side of it. The article concludes with a discussion of policy recommendations for Turkey that could help reduce sex trafficking in this country.
\end{abstract}

\section{INTRODUCTION}

Human trafficking is a serious problem that affects millions of people all over the world. In the single year 2014, more than 44 thousand people were identified as victims of human trafficking globally (US Department of State, 2015: 48). Women and children are particularly vulnerable to sex trafficking. According to the United Nations Office on Drugs and Crime (UNODC, 2014), women and girls constitute 70\% of all victims of trafficking between 2004 and 2011. Trafficking of women and girls for sexual exploitation (henceforth sex trafficking) has several dimensions such as exploitation for prostitution, pornography, sex tourism, and the 'mail-order' bride industry. To combat sex trafficking and to reduce its harmful effects, several policies have been developed and implemented against sex trafficking, both locally and internationally, especially after the acceptance of the United Nations (UN) Protocol to Prevent, Suppress, and Punish Trafficking in Persons, Especially Women and Children in 2000 (see UN, 2000). However, to what extent these responses are effective remains as a question mark, since most local and global anti-trafficking policies are not evaluated nor assessed systematically.

Turkey is particularly affected by sex trafficking because of the large numbers of irregular migrant women that it receives (Erder and Kaska, 2003; Toksoz and Unluturk-Ulutas, 2012). Although there are no available statistics on the exact numbers of migrant women becoming victims of sex trafficking in Turkey apart from those officially identified as "victims" by the police (Coskun, 2015a; 2015b), according to the annual Trafficking in Persons (TIP) Report issued by the United States Department of State (US Department of State, 2015: 340), victims of human trafficking in Turkey are mainly from

\footnotetext{
* Department of International Relations, Bilkent University, Turkey

** Department of Political Science and Public Administration, Giresun University, Turkey
} 
Central and South Asia, Eastern Europe, Syria, and Morocco. Istanbul as the largest metropolitan city in Turkey is the primary destination for human trafficking, followed by other large industrial and tourism cities such as Ankara, Izmir, and Antalya (Karakus and McGarrell, 2012: 4). Turkey's antitrafficking responses have been largely put into force after the UN Protocol was signed, and since then several activities were carried out. However, as Sever et al. (2012: 8) note, "an assessment study has yet to be conducted, regarding the budget and sources allocated to the state policy in combating human trafficking, as well as its accomplishments".

This article aims to conduct such an assessment by answering the following research question: Is the existing policy on sex trafficking in Turkey efficient to provide adequate response to this problem? It starts with a review of the existing studies on sex trafficking in Turkey and continues with an examination of the supply and demand sides of the problem, with Turkey's migration and prostitution regimes being identified as primary factors having an impact on the existence of sex trafficking in Turkey. A summary of the existing policies on sex trafficking in Turkey follows, with a critical assessment of these. Available sources such as literature, research reports, and media reports are utilized in order to provide a comprehensive analysis. The article concludes by arguing that Turkey's policy on sex trafficking provides an inadequate response to the problem by ignoring the patriarchal demand side of sex trafficking and focusing almost solely on the economic supply side of it, thus leading to stigmatization and victimization of migrant women under the impact of Turkey's migration and prostitution regimes. It also proposes some policy recommendations for Turkey.

In any analysis of sex trafficking, it is important to clarify the difference between two opposing positions on the relationship between prostitution and trafficking reflected in the so-called "prostitution/sex work" debate in the feminist literature (Miriam, 2005; Outshoorn, 2005). According to the older "abolitionist" position, the distinction between trafficking and prostitution is blurred because all forms of prostitution are accepted as "forced by definition" (Outshoorn, 2005: 145). The proponents of this view argue in favour of the abolition of prostitution focusing on the gendered nature of violence that it entails. Abolition of prostitution would, in their view, lead to abolition of trafficking (Outshoorn, 2005: 146). In contrast, in the more recent "regulatory" or "pro-sex work" approach, prostitution and trafficking are "delinked" (Outshoorn, 2005: 151). Prostitution is referred to as "sex work", and women involved in prostitution are called "sex workers", to emphasize their active agency in choosing this type of employment (Kempadoo, 2005). However, when these women are denied payments for "sex work" or otherwise exploited, they are considered trafficked women. Thus, in the regulatory approach, trafficking is seen as a form of "forced labour" (Bindman, 1998; Doezema, 2000). However, the problem with "regulatory" approach is that by focusing on the economic side of the problem of prostitution and trafficking, it "degenders" the issue. Furthermore, by seeing trafficking as yet another form of "forced labour", it ignores the patriarchal demand side of it, "as the link to prostitution reminds us that it is usually women who are trafficked for the purposes of men's sexual gratification" (Outshoorn 2005: 147). Therefore, in line with Coskun (2015a; 2015b), in this article the feminist abolitionist position is supported, and both sex trafficking and prostitution are seen as forms of violence against women (Farley, 2004). Trafficking and prostitution are also seen as intrinsically linked to each other and both explained by the dynamics of patriarchal exploitation and gendered violence.

Consequently, in terms of the article's terminology, the term "prostitution" is used rather than the term "sex work". The term "prostitute" is also used here to encompass all women involved in prostitution without implying any disrespect for them. Following Coskun (2015a; 2015b), the concepts of prostitution and migration regimes are also utilized. A prostitution regime is defined here as "a set of policies and practices surrounding prostitution" (Coşkun, 2015a: 5; also see Outshoorn, 2004). The term "migration regime" is used here to refer to a particular set of a country's migration policies (Williams, 2010: 390). Finally, the concept of "victim" is used in this article to underline "the'fragile' and 'vulnerable' position attributed to women who have been trafficked" (Coşkun, 2015a: 5). 


\section{LITERATURE REVIEW}

Sex trafficking has been a popular area of study world-wide in the last two decades. The first study on human trafficking in Turkey dates back to 2003, when Erder and Kaska (2003) published their pioneer research report on irregular migration and trafficking in women in Turkey. It was preceded only by Gulcur and Ilkkaracan (2002) who examined "voluntary" prostitution by migrant women from the former Soviet Union to Turkey from a feminist (regulatory) perspective. Many researchers analysed human trafficking in Turkey from a criminological perspective seeing it as a transnational security challenge for the Turkish state brought about by globalization and the growing activity of organized crime (e.g. Arslan et al., 2006; Narli, 2006; Ozturk and Ardor, 2007; Demir, 2010; Demir and Finckenauer, 2010). Demir and Finckenauer (2010) examined the characteristics of migrant women who were identified as trafficking victims by the police, whereas Atauz et al. (2009) and Bespinar and Celik (2009) analysed the impact of organized crime on human trafficking in Turkey, relying on interviews with different stakeholders on their attitudes to human trafficking. In their study, Atauz et al. (2009: 429-434) found that "knowledge about human trafficking among the interviewees representing different institutions was generally low", and trafficking was often classified "under the umbrella of the entertainment sector".

This lack of knowledge about the problem of human trafficking continues to facilitate negative and stigmatizing societal attitudes towards migrant women in Turkey. Consequently, most of the existing research is explanatory in its nature and aims to increase awareness of the problem of sex trafficking in general. For example, Demir and Erdal (2010) conducted a content analysis of 84 news stories on migration and found that terms related to human trafficking and migration such as migrant smuggling, human trafficking, and asylum were usually misunderstood in the Turkish printed media. Criminological perspective in the analysis of sex trafficking in Turkey continues to be popular among researchers. For example, Karakus and McGarrell (2012) examine human trafficking as transnational crime with a particular focus on the demand side of trafficking. A comprehensive study of the demand side of human trafficking in Turkey has been conducted by Ayata et al. (2008), who also included interviews with Turkish male clients of prostitutes into their analysis.

Important feminist studies such as Kalfa (2008), Cokar and Yilmaz-Kayar (2011) and Ozer (2012) based on interviews with migrant women involved in prostitution and media analysis should also be noted here. Finally, the most recent and very interesting feminist (abolitionist) studies have been conducted by Coskun (2014a; 2015a; 2015b) who examined the role of "consent" in sex trafficking and the impact of prostitution and migration regimes in Turkey on its struggle against human trafficking, based on interviews with key informants directly related to the field of human trafficking. Similarly to Gulcur and Ilkkaracan (2002), Coskun (2014a; 2015a; 2015b) can be praised for making migrant women themselves the focus of her feminist analysis.

In general, three problems can be identified with the existing literature on sex trafficking in Turkey. First of all, the problem of sex trafficking is often portrayed as a security issue which threatens the national identity of the Turkish state (see Narli, 2006; Isigicok, 2010). However, this securitization discourse is problematic because it leads to the portrayal of sex trafficking as an "illegal" border crossing issue rather than a human rights issue, and emphasis in policy-making is thus placed on the security of states rather than the security of individuals (see Dauvergne, 2008; Dewey, 2008; Lobasz, 2009; Anderson, 2013). Among the existing research, Agathangelou (2004), Atauz et al. (2009) and Coskun (2014a; 2015a; 2015b) all point to the fact that securitization discourse on the problem of human trafficking only pushes the state for even more restrictive policies, thus leaving trafficked women and all migrant women in general vulnerable and unprotected.

Second, among the reasons behind sex trafficking, the economic explanation is the prevailing one, with almost all researchers agreeing that the reason for sex trafficking in Turkey is poverty and social unrest in the neighbouring countries (e.g. Kirisci, 2007; Icduygu, 2009). Poverty is 
accepted as the most important "push" factor for the migrant women (Icduygu, 2009). However, such an explanation leads to the portrayal of Turkey as "unquestionable" by putting the blame for sex trafficking on the nearby countries and their women and focusing only on the supply side of the argument. The problem is that the demand side of sex trafficking and prostitution, shaped by patriarchal societal structures, is not mentioned by most authors, with only some exceptions (such as Agathangelou, 2004; Ayata et al., 2008; Kalfa, 2008; Bespinar and Celik, 2009; and Baykotan, 2014). Patriarchal traditions of subordination of women to men, as well as societal attitudes to sexuality in the Turkish society creating demand for prostitution involving migrant women, are not discussed in most accounts.

Finally, the existing works usually lack substantial criticism of the government policies on sex trafficking, looking more like a summary of the existing efforts and successes. The only exceptions are Agathangelou (2004), Atauz et al. (2009), Toksoz and Unluturk-Ulutas (2012), Baykotan (2014) and Coskun (2014a; 2015a; 2015b), which contain extensive critiques of the existing policies on sex trafficking. Therefore, we aim to contribute to this gap in the literature by providing a critical assessment of the existing policies on sex trafficking in Turkey through the analysis of both the economic (the supply side) and the patriarchal (the demand side) dimensions of it, examining sex trafficking at the intersection of Turkey's migration and prostitution regimes.

\section{SEX TRAFFICKING IN TURKEY: MIGRANT BODIES FOR SALE}

\section{The scope of the challenge}

Turkey became a destination country for migrant women especially after the demise of the Soviet Union (Erder and Kaska, 2003). Thousands of female migrants from impoverished post-Soviet countries sought ways to work in Turkey because of its lax visa policies and relative geographical proximity (Kalfa, 2008; Toksoz and Unluturk-Ulutas, 2012). Whereas many migrant women came to Turkey to search for jobs as domestic workers, waitresses or interpreters (Kalfa, 2008), most of them ended up working in the informal sectors of the labour market such as entertainment and tourism where they were vulnerable to exploitation and trafficking (Erder and Kaska, 2003; Toksoz and Unluturk-Ulutas, 2012; Coskun, 2015a).

According to the International Organization for Migration (IOM), the majority of women and girls who become victims of sex trafficking in Turkey come from the former Soviet Union countries (IOM, 2008). Whereas previously Moldova, Ukraine and Russia were the primary countries of origin for victims of human trafficking, most recent human trafficking victims in Turkey come from Central Asian countries such as Turkmenistan, Uzbekistan and Kirgizstan, and also from Azerbaijan (Ozer, 2012; Sever et al., 2012). The growing numbers of victims are also from Syria and Morocco (US Department of State, 2015). Most victims of sex trafficking enter Turkey legally with a tourist visa, but subsequently overstay. The cities of Istanbul, Antalya, and Trabzon are the main ports of entry for the trafficked individuals (Demir and Finckenauer, 2010).

While some of migrant women might come to work in prostitution in Turkey of their own free will, others are deceived by the traffickers and forced to comply (Demir, 2010; Demir and Finckenauer, 2010). There are various recruitment techniques used by sex traffickers in Turkey. Some of them recruit their victims by promising jobs in the housekeeping or entertainment sectors, later forcing them to prostitution by signing a fraudulent job contract (Erder and Kaska, 2003). This is done by using coercion and pressure, as well as by confiscating the victim's identification documents. Using several coercion tactics, traffickers "make victims feel more desperate and hopeless, then victim resistance is disabled and they have to obey the rules" (Demir, 2010: 334). Thus, sex trafficking can be claimed to be a serious danger for migrant women coming to search for a better living in Turkey. 


\section{The supply side of sex trafficking in Turkey and Turkey's migration regime}

The supply side of sex trafficking is particularly influenced by the economic factors and Turkey's migration regime. After the collapse of the Soviet Union, many women in the countries of the former Soviet bloc were deprived of economic opportunities and state support programs that had previously been available (Gulcur and Ilkkaracan, 2002). Because of economic problems that they faced, many women from former Soviet countries left their communities choosing Turkey as a better place to live. Women from other countries also choose to migrate to Turkey because in their home countries they were constrained by structural economic problems such as unemployment (Erder and Kaska, 2003). For example, an African migrant woman interviewed in Kumkapi (Istanbul) by Coskun (2014b) explains why she came to Turkey: "I came to Istanbul because there was no job in the place where I lived ... I came to work here in order to provide a better life for my family." The economic expectations of migrant women were often not met in Turkey, making it even more difficult for them to adapt to a new and unfamiliar social environment. Therefore, it was easy for migrant women to fall prey to sex traffickers.

The recent Syrian crisis has also contributed to the increase in the number of displaced Syrians fleeing to Turkey (see Ozden, 2013; Demir, 2015). Currently, Turkey is hosting over 2.7 million Syrian refugees $^{1}$ (DGMM, 2016). Except for 10 per cent of them who are accommodated in refugee camps, all the others live outside the camps (DGMM, 2016). Over half of displaced Syrians are children. Moreover, more than 75 per cent of them are women and children in need of special protection. Since they do not have work permits to make their living, most Syrians work without permits, even in unsafe jobs. That makes them particularly vulnerable. According to several recent media reports, Syrian girls and women are often sold into marriages with Turkish citizens, which can be considered a form of sex trafficking in itself (e.g. Haberturk, 2014; Sozcu, 2015; T24, 2015).

Despite the seriousness of the problem, it can be argued that Turkey's migration regime has not provided an adequate response to sex trafficking of migrant women (Coskun, 2015a; 2015b). It has been reported to be extremely difficult for migrant women to enter Turkey's formal economy by obtaining official residence and work permits (Toksoz and Unluturk-Ulutas, 2012). According to the Law No. 4817 on Work Permits for Foreigners (Yabancilarin Calisma İzinleri Hakkinda Kanun, 2003), the Ministry of Labour and Social Security is the sole institution responsible for issuing work permits. It "grants permission to the employment of ... [foreigners] given that domestic labourers cannot be found for any particular area of employment" (Toksoz and Unluturk-Ulutas, 2012: 86). Because of these strict conditions of formal employment, most migrant women work illegally with no work permits. For example, Erder and Kaska (2003: 15) found that only 13 per cent of migrants who have residence permits also have work permits. Since, for example, in the year 2011 the share of female migrants in the total percentage of migrants holding work permits was estimated as 42.1 per cent (Toksoz et al., 2012: 53), it can be concluded that very few migrant women are legally employed in Turkey.

However, because of their involvement in the informal labour market and their inability to find legal employment, migrant women in Turkey are very vulnerable in the face of human rights violations and harassment, and are not protected by the existing policies and laws because of their "illegal migrant" status (Toksoz and Unluturk-Ulutas, 2012; Coskun, 2015b). It has been argued that migrant women have been stigmatized and sexually harassed in their work places because of their "foreign" looks, and thus have been very vulnerable to all kinds of exploitation and even trafficking (Gulcur and Ilkkaracan, 2002; Toksoz and Unluturk-Ulutas, 2012; Coskun, 2015a; 2015b). The women's status as "illegal migrants" also prevented them from getting any help from the police because of their fear of deportation (Coskun, 2015b: 334). Thus, by regulating the supply side of irregular migration into Turkey in general, Turkey's restrictive migration regime has left migrant 
women unprotected and easily subjected to exploitation, with the result that many of them become victims of sex trafficking (Coskun, 2015b).

\section{The demand side of sex trafficking in Turkey and Turkey's prostitution regime}

The demand side of sex trafficking in Turkey is particularly affected by the prevailing patriarchal attitudes to men and women's sexuality, as well as Turkey's prostitution regime. In feminist literature, the term "patriarchy" has come to mean men's domination over women "as male control over women's fertility" (Barrett, 1988: 12). Traditional patriarchal structures of the Turkish society such as subordination of women to men and submissiveness of women in general are maintained by the institutions of family, marriage, media, and the state (see Zengin, 2011). Prostitution and sex trafficking have some deep cultural roots in the peculiarities of Turkish sex culture and societal attitudes to sex. For example, in the traditional Muslim societies having sexual intercourse before marriage is considered unacceptable for women. Therefore, Turkish women are expected by the society to protect their virginity (symbolizing purity and decency) until marriage. For example, in a study conducted in 2006 by the Society for Sexual Education, Treatment and Research in Turkey, it was found that 63 per cent of the interviewed men "completely agreed with the statement "virginity shows female decency", and 65 per cent of them completely agreed with the statement "Women should remain virgins until they get married"" (Balseven-Odabasi et al., 2012: 157). Thus, having a sexual intercourse before or outside marriage for women is a taboo in the Turkish culture; it can become a source of shame for a Turkish woman and is generally considered as an immoral deed (Kaya and Aslan, 2013; Coskun, 2014a).

Because of these patriarchal attitudes to sexuality, Turkish men of all social groups often resort to the services of prostitutes in order to get sexual experience before or outside of marriage (Ayata et al., 2008; Cokar and Yilmaz-Kayar, 2011). In the male-dominated society, there is a prevailing biological explanation for the inevitability of the existence of prostitution in Turkey (see Ayata et al., 2008; Bespinar and Celik, 2009). In this biological perspective, the existence of prostitution in Turkish society is perceived as inevitable because the sexual appetite of the Turkish men is seen as a natural thing (Ayata et al., 2008). As a non-governmental organization (NGO) representative interviewed by Bespinar and Celik (2009: 7) puts it, "there is a demand in this land ... The man requests it. It is the biological desire, sexual hunger, societal suppression of sexuality, inclination to changes and polygamy ... that drive the demand."

However, Turkey's prostitution regime has not been successful in addressing this demand, and there have been very few legal attempts to regulate it. One of them is the Turkish Regulation against the Spread of Sexually Transmitted Diseases through Prostitution and the Provisions Regulating Prostitutes and Public Houses (Ministry of Justice, 1961), which is an official document regulating "legal" employment in prostitution in Turkey. It was adopted in 1961 and amended in 1973, and no changes have been made since then. The Regulation allows the existence of authorized brothels (genelevler) in Turkey where prostitution can be performed under strict control of the relevant authorities. According to the Regulation, "women have to be at least 21 years old and Turkish citizens to work in brothels. They also have to be examined in a Skin and Sexually Transmitted Diseases Hospital twice a week" (Balseven-Odabasi et al., 2012: 153). Migrant women, however, cannot legally work in state-run brothels (also see Passport Law, 1950). Therefore, "there is "zero tolerance" policy against street prostitution and irregular prostitutes" in Turkey (Coskun, 2015a: 7), which means that any migrant woman can easily be detained by the police on suspicion of being a prostitute, subjected to compulsory medical examinations for sexually transmitted diseases (STDs) ${ }^{2}$ and then deported for disturbing the public order.

Yet it is possible to argue that Turkey's prostitution regime regulated by the 1961 Regulation which is more than half a century old no longer reflects the realities of contemporary demand for 
prostitution in Turkey (Kuntay and Cokar, 2007). First of all, with the invention of mobile phones scheduling a meeting with a prostitute has become very easy, and the necessity for the existence of state-run brothels has declined (Erder and Kaska, 2003: 47; Ayata et al., 2008). Second, there seems to be a persistent demand for migrant women in prostitution in Turkey (Kalfa, 2008; Ozer, 2012). Migrant women are sexually desirable by Turkish men because of their "exotic" bodily characteristics such as whine skin, blond hair, long legs, and green/blue eyes (Agathangelou, 2004). They are expected to "willingly" fulfil the sexual desires of men because of their "looseness" compared to local Turkish women who, in contrast, are seen as chaste "wives and mothers" responsible for the Turkish men's honour (namus) and cannot therefore be viewed as sexual objects (Baykotan, 2014; Coskun, 2014a). According to Zengin (2011: 32, emphasis original), "societal rules and norms creating general perception of namus in Turkey codes the women's bodies not as their own property, but as the property of men, family or the society". But in the case of migrant prostitutes, the connection between family and women's body is destroyed, and migrant women' bodies are seen as belonging to everyone (Zengin, 2011: 32-33).

Because of the media portrayals of migrant women as "willingly" coming to Turkey in order to engage in prostitution for economic profits (see Erder and Kaska, 2003; Ayata et al., 2008), the patriarchal demand side of prostitution is made invisible in Turkey's prostitution regime, and prostitution is portrayed solely as the problem of economic supply explained by poverty of the sending states whose women choose prostitution because they are "unchaste" (see Ayata et al., 2008). Because of such one-sided portrayal of the problem of prostitution as stemming from the "looseness" of migrant women, there is no criminal responsibility for using the services of a prostitute in Turkey, whether it is a local or a migrant woman, and men resorting to these services are not stigmatized by the Turkish society. On the contrary, the Turkish men are often portrayed in the media as "victims" of migrant prostitutes who seduce them (Erder and Kaska, 2003, Ayata et al., 2008; Coskun, 2015a). Similarly, after the police raids when migrant women involved in prostitution are "caught" and later deported, the Turkish clients usually go free (Coskun, 2015a; 2015b). They are neither subjected to medical examinations for STDs nor kept in custody (Coskun, 2015b). This tolerance for the men's sexual appetite is an important socio-economic factor that shapes the demand side of prostitution involving migrant women in Turkey (Ayata et al., 2008).

Since the demand side of prostitution is made invisible by the prostitution regime, migrant women in Turkey are usually blamed for their own indecency. For example, in the 1990s women who came from ex-Soviet countries and took employment in Turkey were stigmatized as "whores" and "Natashas" (see Hughes, 2000; Gulcur and Ilkkaracan, 2002; Erder and Kaska, 2003). It was argued that they sold sex for money because they enjoyed this activity due to their own looseness. Migrant women were also often held responsible for the breakup of families and the spread of STDs such as AIDS (Gulcur and Ilkkaracan, 2002; Erder and Kaska, 2003; Ayata et al., 2008). The media in particular focused mostly on the public health and morality aspect of the problem of prostitution, discussing the dangerous role of migrant women in the spread of STDs in Turkey and portraying Turkish men as "victims" of "migrant prostitutes" who jeopardize traditional values and public morality (see Bayer, 2000; Erder and Kaska, 2003; Ayata et al., 2008; Coskun, 2014a). Because of such media portrayals, many members of the Turkish society were not adequately informed about the victimization of migrant women who could be exploited in prostitution against their will.

However, the most significant problem with Turkey's prostitution regime is the fact that these patriarchal attitudes to all migrant women, especially those coming from former Soviet countries, as "willing prostitutes" and "Natashas" is itself a factor pushing these women into prostitution (Kalfa, 2008; Toksoz and Unluturk-Ulutas, 2012; Coskun, 2014a; 2015a; 2015b). Exposure to sexual harassment, abuse, and racist and sexist attitudes can become a source of a deep psychological trauma in migrant women, and the discrimination and social stigmatization of women who have been sexually assaulted lead to the feelings of guilt and hopelessness, making the women think that 
they do not deserve anything else but being in prostitution (Kalfa, 2008; Balseven-Odabasi et al., 2012; Toksoz and Unluturk-Ulutas, 2012). Thus, migrant women can easily become victims of sex trafficking because of stigmatizing attitudes to them as "willing" prostitutes and patriarchal attitudes to sexuality in Turkey, which is influenced by Turkey's prostitution regime that focuses only on the public health and morality aspects of the problem, leaving migrant women unprotected.

\section{TURKEY'S POLICIES AGAINST SEX TRAFFICKING}

This section is an overview of the existing policies and laws on human trafficking in Turkey, followed by its criticisms. Prior to 2002, there was no direct reference to sex trafficking in the Turkish legal system. In the early 2000s, Turkey was criticized for its lack of attention to the problem of sex trafficking. Turkey was placed on Tier 3 in the US Department of State TIP Report 2001. Tier 3 is designed for "countries whose governments do not fully comply with the minimum standards [of the Trafficking Victims Protection Act] and are not making significant efforts to do so" (US Department of State, 2015: 53). Since then, Turkey has undertaken several efforts to increase awareness of sex trafficking among its population and develop a better policy against trafficking, resulting in its placement on Tier 2 in 2005. Tier 2 is designed for "countries whose governments do not fully comply with the Act's minimum standards but are making significant efforts to bring themselves into compliance with those standards" (US Department of State, 2015: 53). However, it has been several years, and Turkey still remains on Tier 2 as of 2015 (US Department of State, 2015: 54).

In order to fulfil the provisions of the UN Convention against Transnational Organized Crime and its Additional Protocols, in August 2002 anti-trafficking amendments to the Turkish Criminal Code were prepared by the Ministry of Justice and adopted by the Parliament. Through this legal arrangement, Law No. 4771 added Articles 201/a-b to the Turkish Criminal Code. These amendments introduced the definition of human trafficking into the Turkish legal system for the first time, as required by the UN Protocol against Trafficking in Persons. The 2002 amendments prescribed five to ten years of prison for organization of human trafficking (Icduygu, 2009).

In June 2005, among other efforts to harmonize Turkish legislation with the European Union (EU) legislation following the accession negotiations, a new Criminal Code was adopted. Article 80 of the Turkish Criminal Code replaced Article 201/b. The new Article 80 foresees sentences from eight to twelve years of imprisonment for the organization of human trafficking (Turk Ceza Kanunu, 2004). In addition to human trafficking, instigating women and children into prostitution is also prohibited. Article 227 "Organization of Prostitution" of the Turkish Criminal Code regulates punishments for those who instigate people into prostitution (Turk Ceza Kanunu, 2004).

Another important legislative development took place in June 2003, when amendments were made to the Article 5 of the Citizenship Law No. 403 (Vatandaslik Kanunu, 2009). According to the amendments, a three-year probation period is now required in order to obtain Turkish citizenship through marriage (Vatandaslik Kanunu, 2009). If a married couple is not living in the same household, it is no longer possible for the foreign spouse to apply for Turkish citizenship, and the police may routinely control the couple (Vatandaslik Kanunu, 2009). Although the amended law aimed to reduce the number of trafficking victims in Turkey by preventing trafficking through paper marriages that were reported to be used by traffickers to ensure migrant women's stay in Turkey (Icduygu, 2009), it can be argued that it actually made migrant women more vulnerable to exploitation in prostitution because it is now more difficult for them to obtain legal status by obtaining Turkish citizenship (Coskun, 2015a).

One of the most recent developments was the adoption of Law No. 6458 on Foreigners and International Protection by the Turkish Parliament in April 2013 (see DGMM, 2014). The new law provides new protection rules for refugees, asylum-seekers, and victims of human trafficking. 
Articles 48 and 49 of this law deal with residence permits for victims of human trafficking, their extension, and annulment. A new Department for the Protection of Victims of Human Trafficking in the Directorate General of Migration Management (DGMM) has also been established according to the Article 108 of this Law.

One more significant achievement was the establishment of an emergency toll-free helpline for victims of human trafficking that came to be known as "Alo 157". This helpline can be reached 24/7 from any part of Turkey and also from mobile phones (Arslan et al., 2006). The line provides information to individuals who face the risk of sex trafficking, including procedures for visas and safe return of victimized migrants to their home countries. The services of the helpline are provided in Russian, Romanian, English, French, and Turkish. The helpline was opened to international calls in April 2007 and is still operational as of 2015 (Ministry of Foreign Affairs, 2015).

Since 2005, Turkish institutions increased their efforts to combat trafficking. Major Law enforcement agencies (police and gendarmerie) have established special divisions to combat human trafficking, and provided trainings for them. Several bilateral and multilateral agreements have been signed with source countries of trafficking such as Georgia, Moldova, Ukraine, and Kyrgyzstan. Cooperation with NGOs and International Organization for Migration (IOM) in victim identification and victim assistance have been increased and developed. According to the latest TIP Report issued by the US Department of State, more than 100 potential trafficking victims were rescued during the 30 operations conducted by the Turkish National Police in 2014 (US Department of State, 2015: $341)$.

The role of the IOM has been very important in the sex trafficking prevention efforts in Turkey in terms of organizing and funding anti-trafficking projects. IOM has taken a role, mainly since 2003, to promote activities against human trafficking in Turkey. Several training programmes were held by IOM for the personnel of law enforcement agencies as well as judicial institutions in Turkey. IOM has been dealing with the voluntary return programmes of trafficked victims in Turkey. Moreover, IOM has funded several research projects that investigated the most problematic areas of the trafficking phenomenon such as demand side of trafficking (Ayata et al., 2008) and Turkey's trafficking victim identification process (Sever et al., 2012). ${ }^{3}$

Three non-governmental organizations have been actively participating in anti-trafficking efforts. Human Resources Development Foundation in Istanbul, Women's Solidarity Foundation in Ankara, and Association of Family Counsellors in Antalya have been operating shelters that are specifically designed for the protection of victims of trafficking. Those who are accommodated in these shelters are provided with physical and psychological treatment, vocational courses, and legal assistance (Sever et al., 2012). Except for these three, the involvement of non-governmental organizations in anti-trafficking efforts is scarce and weak. The only exception can be the Network to Fight against Child Sexual and Commercial Exploitation that conducts anti-child trafficking campaigns and trainings country-wide (see CTCS, 2015).

\section{CRITICISM OF POLICIES}

Despite a significant progress in Turkey's policies against sex trafficking since the adoption of the UN Palermo Protocol, there exist a number of major problems. The main problem is that Turkey's current anti-trafficking policies are not victim-centred but state-centred. In this regard, one of the most serious problems with the existing policies is the fact that although there are many irregular migrant women staying on Turkish territory, the protection mechanisms are inadequate to prevent their exploitation (Sever et al., 2012; Coskun, 2014a; 2015a; 2015b). The restrictive migration policies of the Turkish state such as denying migrant women the possibility to obtain residence and work permits in an easy and efficient way, as well as the absence of laws to protect these women push them into the informal labour market, where they can easily fall prey to traffickers (see 
Toksoz and Unluturk-Ulutas, 2012; Coskun, 2015a; 2015b). Although there is no possible way for migrant women to engage in prostitution in Turkey legally, they are stigmatized as "illegal" prostitutes by the migration and prostitution regimes (Coskun, 2014a; 2015a). Many migrant women also face discrimination and sexual harassment which can push them into prostitution against their will (Gulcur and Ilkkaracan, 2002; Kalfa, 2008; Toksoz and Unluturk-Ulutas, 2012). The existing antitrafficking policies in Turkey do not prevent migrant women attracted by economic opportunities in this country from being exploited in prostitution (Agathangelou, 2004).

Second, there is a problem with lack of understanding of the problem of sex trafficking in Turkey. This problem is particularly affected by patriarchal attitudes to sexuality in the Turkish society, as well as prejudices against migrant women in general. The prevailing attitude to migrant women in Turkey is negative and stigmatizing, and it is commonly thought that if they are involved in prostitution it means that they are selling sex for money of their own free will. For example, in Turkey, it is legally accepted that a prostitute expresses her "consent" to be in prostitution when she accepts money for the sexual act (Coskun, 2014a; 2015a; 2015b). However, it can be argued that the problem of consent is not relevant for sex trafficking discourse, because it is very difficult to prove the degree of consent of the victims to work as prostitutes, since many of them are deceived by the traffickers. Even if a woman knows that she is coming to Turkey for prostitution, she is sometimes deceived about the working conditions and payment (see Demir, 2010; Demir and Finckenauer, 2010). In general, migrant women continue to be stigmatized for coming to Turkey in order to engage in prostitution because of their own "looseness" (Agathangelou, 2004; Atauz et al., 2009). It seems that the current emphasis in the anti-trafficking policies in Turkey is simply on establishing the difference between a "voluntary" prostitute (stigmatized as "loose") and "involuntary" victims of human trafficking (perceived as innocent) (see Aradau, 2008). The whole system of victim protection is based on the identification of women precisely as victims of human trafficking. Two criteria are used by the police to identify migrant women as victims: receiving money or other benefits (such as mobile phones) from the traffickers, and recruitment in the women's home countries or "forcible transportation" into Turkey (Coskun, 2015a; 2015b). Yet, instead of focusing on establishing the difference between "voluntary" and "forced" prostitution, it would be much more relevant to accept that being in prostitution is never an "expression of pure free will" (Agathangelou, 2004: 61), and therefore, to include all migrant women in the protection system. It can be argued that policies against sex trafficking in Turkey will remain inefficient as long as they are not connected to migration and prostitution regimes in general (see Coskun, $2014 \mathrm{a} ; 2015 \mathrm{a} ; 2015 \mathrm{~b})$. The emphasis in the policies should be on the women's experiences themselves and on their protection rather than on determining the degree of the victim's consent to become a prostitute.

Third, efforts should be made to change the portrayal of migrant women involved in prostitution as a security threat to the Turkish state. Patriarchal attitudes to sexuality prevailing in the Turkish society such as cultural norms about namus further exacerbate the problem. Turkey continues to maintain the ideological stance that migrant women involved in prostitution are a security threat disturbing the national order (Agathangelou, 2004). Such an argument puts the blame for the existence of sex-trafficking in Turkey on migrant women themselves who are referred to as "Natashas" and are criticized and stigmatized for destroying the institution of the family, damaging social health and morality, and undermining national security in general. But at the same time, there is a persistent demand for migrant prostitutes in Turkey, and the images of migrant women (especially from the former Soviet countries), ready to do anything for money, are eroticized in Turkish culture (Agathangelou, 2004: 123). Similarly, the recent influx of Syrian displaced persons is argued to pose a threat to the institution of the family in Turkey, especially in its south-eastern provinces. According to some recent data, there is an increase in divorces among the Turkish families because of "Syrian brides" who are claimed to jeopardize the traditional family relations and public order (Haber Turk, 2014). There has been a growing local interest in Syrian women and girls who are 
reported to be trafficked for sexual exploitation by marriage with Turkish citizens (see Haberturk, 2014; US Department of State, 2015). However, this demand for migrant women is not acknowledged in Turkey's anti-trafficking policies.

Finally, probably the most significant problem with the existing policies is the fact that deportation of a migrant woman involved in prostitution to her home country is seen as the ultimate solution to sex trafficking. Even if a migrant woman has a valid visa, she can be easily deported for engagement in prostitution or for carrying an STD (Coskun, 2014a; 2015a; 2015b). Similarly, migrant women identified as victims of human trafficking by the law enforcement agencies receive a 6-month humanitarian visa only for the purposes of medical or psychological treatment, and are deported after testifying against their traffickers. A migrant woman not identified as a victim of human trafficking but labelled as "voluntary" prostitute can be deported if she is detected with an STD. Coskun notes that with such policies, Turkish society's health is protected "at the expense of the 'foreigner's' health" (Coskun, 2014a: 198). The solutions offered to sex trafficking victims by the Turkish government are voluntary repatriation to their home countries, and having a residence permit if she accepts to cooperate with judicial authorities and testify against traffickers. The fact that issuing a "humanitarian" residence permit is tied to the victim's cooperation with the police and the judicial authorities (which means filing a formal complaint and testifying against her abusers in court) is especially problematic (Coskun, 2015a; 2015b). With such conditional protection of the women, the "fate of the victim" can easily turn into "a fate of a witness, which entails permission to remain in the territory of the receiving state for the purposes of the criminal prosecution of the traffickers" (Stoyanova, 2011: 784, emphasis original). Coskun notes that according to her data, since 2000 each year the number of migrant women deported from Turkey for engagement in prostitution or having an STD was almost 10 times higher than the number of the women voluntarily repatriated as victims of human trafficking (Coskun, 2014a: 201). These statistics raise questions about the efficiency of Turkey's policies against sex trafficking and the management of the sex sector in general. It has also been reported that in many cases, victims refused to testify against their traffickers because of fear or threats and thus lost their right to receive a "humanitarian" residence permit, choosing immediate repatriation (Coskun, 2015a). In fact, many women who were actually victims failed to be identified as such by the police because they did not fit the pre-defined criteria about "not receiving payments" from their traffickers or being "recruited" in their home countries (Coskun, 2015b), thus making the official statistics unreliable. Because of these pre-defined criteria for trafficking victim identification in Turkey, the judicial response to the crime of trafficking has been stalled. Coskun (2015a: 13) argues that according to her lawyer informants, "most human trafficking crimes [in Turkey] are interpreted as forced prostitution crimes [according to Article 227], thus resulting in 1-2 years of prison as opposed to the 8-12 years for human trafficking" prescribed by Article 80 (Coşkun, 2015a: 13). Therefore, it is possible to argue that "in view of how the prostitution regime works in Turkey, the distinction between forced and voluntary prostitution may not be meaningful" at all (Coşkun, 2015b: 336). Instead of trying to determine who is a "voluntary" prostitute and who is a trafficking "victim", the Turkish state should focus on protecting all migrant women in general because of their vulnerable status and also on targeting the demand side of prostitution and sex trafficking.

\section{SUMMARY AND CONCLUSIONS}

Sex trafficking is intrinsically connected to prostitution, with both of them exploiting women's sexuality in sexual and economic ways and representing a form of violence against women. This article examined the existing policies against sex trafficking in Turkey with a particular emphasis on migrant women trafficked into Turkey for sexual exploitation. The supply and demand sides of sex trafficking explained by economic and patriarchal factors have been discussed under the impact of 
Turkey's migration and prostitution regimes. Because of the existing restrictive rules on migration, patriarchal attitudes to sexuality and stigmatization of migrant women as "loose", many of them are vulnerable to exploitation and trafficking. It can be argued that the existing policy against human trafficking in Turkey is not efficient enough, despite significant progress made since the adoption of the UN Protocol. Five problems with the existing policies were identified in this study: non-inclusion of migrant women illegally staying on the territory of Turkey in the legal system; lack of information about and understanding of the problem of sex trafficking in the Turkish society in general; portrayal of migrant prostitutes as a security threat to the state; the use of deportation/repatriation as an ultimate tool in dealing with migrant women engaged in prostitution or identified as victims of human trafficking; and problems with victims identification process based on establishing the women's "consent".

The following policy recommendations are proposed to the Turkish government in order to protect migrant women against sex trafficking in Turkey. First of all, to ensure better protection of all migrant women, easier access to residence and work permits should be provided. More shelters and protection centres for migrant women facing sexual violence that would offer free food, clothing, psychological and legal counselling should be opened. Second, migrant women involved in prostitution should be allowed to receive treatment for STDs in Turkey, without compulsory deportation for treatment in their home countries. The Turkish government should recognize that the reasons for the existence of sex trafficking in Turkey are not limited to the supply factors such as poverty of the nearby countries, but admit that there is a persistent demand for migrant women in the Turkish sex sector. Therefore, demand reduction can be a part of anti-trafficking policies. Amendments to the Turkish Criminal Code should be made in order to make men "accountable" for buying sex so that instead of being allowed to walk free after prostitution raids, the clients could be detained by the police and questioned at the police stations. Furthermore, attempts should be made at changing patriarchal attitudes to sexuality in the Turkish society through educational campaigns. Instead of being stigmatized, both local and migrant women involved in prostitution should be treated as the "the injured party" without questioning ... [their] "consent" because of the unequal relations, gender-based violence and coercion inherent in prostitution" (Coskun, 2015a: 17) and provided with exit opportunities such as vocational courses. Furthermore, the media is recommended to change the discourse of portraying migrant women as a security threat to Turkey, admitting that supply of migrant women from the neighbouring countries will persist as long as there is a patriarchal demand for "sexually available" migrant women in the Turkey's sex industry. In order to increase public awareness of sex trafficking and to change the common understanding of prostitution involving migrant women as "voluntary prostitution", more documentaries and short films about trafficking could be broadcast on the Turkish television. In the aftermath of these policies, more migrant women would be better protected against all kinds of exploitation, and less of them would fall prey to human traffickers.

\section{NOTES}

1. Although Turkey is a signatory of the 1951 Convention on the Status of Refugees, it accepted the Convention with a "geographical limitation" meaning that Turkey only grants asylum and refugee status to "persons who have become refugees as a result of events occurring in Europe" (Ozden, 2013: 5). Therefore, Syrians who have fled to Turkey are considered as "guests" and do not have a recognized "refugee" status, being only offered "temporary protection" from the Turkish state, which makes them vulnerable to exploitation because of their unclear status (Ozden, 2013).

2. The fact that migrant women detained for prostitution in Turkey are subjected to forced medical examinations and tests raises serious concerns in terms of human rights. According to Coskun (2015b: 340), "the procedure is not just 'ethically problematic' but also against women's human rights as it requires vaginal/ 
gynaecological examinations by force, which was criticized as 'instrumental rape' even in the late 19th century" (also see Bindel and Kelly, 2003: 4).

3. For more information on IOM's activities in Turkey, see www.countertrafficking.org

\section{REFERENCES}

Agathangelou, A.M.

2004 The Global Political Economy of Sex: Desire, Violence, and Insecurity in Mediterranean Nation States. Palgrave MacMillan, New York.

Anderson, B.

2013 Us and Them: The Dangerous Politics of Immigration Controls. OUP, Oxford.

Aradau, C.

2008 Rethinking Trafficking in Women: Politics Out of Security. Palgrave MacMillan, New York.

Arslan, C., I. Temel, and Y. Aydin, et al.

2006 Combating Trafficking in Turkey: A Strategic Approach to Law Enforcement, International Organization for Migration, Ankara.

Atauz, S., E. Akbas and R. Atasu-Topcuoglu

2009 "Human Trafficking in Turkey: Findings from North-eastern Anatolia", Asian and Pacific Migration Journal, 18(3): 419-440.

Ayata, A., F. Acar, and H. Rittersberger-Tilic, et al.

2008 Türkiye'de Insan Ticaretinin Farkli Formlarina Olan Talebin Incelenmesi, Ministry of the Interior, Ankara (in Turkish).

Balseven-Odabasi, A.B., S. Sahinoglu, Y. Genc, et al.

2012 "The Experiences of Violence and Occupational Health Risks of Sex Workers Working in Brothels in Ankara", Balkan Medical Journal, 29(2): 153-159.

Barrett, M.

1988 Women's Oppression Today, (2nd edition), Verso, London.

Bayer, Y.

2000 "Uyanın, AIDS Turkiye'yi sarıyor", Hürriyet, March 25 (in Turkish).

Baykotan, C.

2014 "Human Trafficking in Turkey: A Feminist Analysis", Fe Dergi, 6(2): 14-24.

Bespinar, F.U., and K. Celik.

2009 "Insan Ticaretinin Görünen Yüzü: Türkiye'de Farkli Sosyal Aktörlerin Seks Ticaretine Bakisi", paper presented at International Davraz Congress on Social and Economic Issues Shaping The World's Future, held at Suleiman Demirel University, Isparta (in Turkish).

Bindel, J. and L. Kelly

2003 A Critical Examination of Responses to Prostitution in Four Countries: Victoria, Australia, Ireland, the Netherlands, and Sweden, Child \& Woman Abuse Studies Unit (CWASU). London Metropolitan University, London.

Bindman, J.

1998 "An international perspective on slavery in the sex industry", in K. Kempadoo and J. Doezema (Eds), Global Sex Workers: Rights, Resistance and Revolution, Routledge, New York and London: 65-69.

Cokar, M., and H. Yilmaz-Kayar.

2011 Seks Isçileri ve Yasalar: Türkiye'de Yasalarin Seks Isçilerine Etkileri ve Öneriler, Human Resources Development Foundation, Istanbul.

Coskun, E.

2014a "Türkiye'de Göçmen Kadınlar ve Seks Ticareti”, Çalışma ve Toplum, 3: 185-206.

2014b "Burada ilk ögrendigim kelime "kaç para", http://www.sosyalistfeministkolektif.org/bedenimiz/ erkek-siddeti/849-telefonla-konusur-gibi-yap-p-seks-seks-diye-soruyorlar.html (accessed 3 March 2016).

2015a "Consent" Issue in Sex Trafficking and Evidence from Turkey"”, Social Politics 13 August 2015.

2015b "Curbing sex trafficking in Turkey: The policy-practice divide", Asian and Pacific Migration Journal, 24(3): 327-352. 
CTCS Mucadele Agi.

2015 "Çocuklara Yönelik Ticari Cinsel Sömürüyle Mücadele Agi,” http://ctcs-mucadele.net/ (accessed 3 March 2016).

Dauvergne, C.

2008 Making People Illegal: What Globalisation Means for Migration and Law. Cambridge University Press, Cambridge.

Demir, O.O.

2010 "Methods of Sex Trafficking: Findings of a Case Study in Turkey", Global Crime, 11(3): 315-336.

2015 "Migration Policies, Social Concerns, and Syrian Refugees in Turkey", GLOBAL Policy and Strategy Policy Paper \#1, Centre for Migration Studies, Ankara.

Demir, O.O. and H. Erdal

2010 "Yasadışı Göç ile İlgili Kavramların Doğru Anlaşılamaması Sorunu ve Yazılı Basında Çıkan Haberler Üzerine Bir İnceleme", Polis Bilimleri Dergisi, 12(1): 29-54 (in Turkish).

Demir, O.O. and J.O. Finckenauer

2010 "Victims of Sex Trafficking in Turkey: Characteristics, Motivations, and Dynamics", Women \& Criminal Justice, 20(1-2): 57-88.

Dewey, S.

2008 Hollow Bodies: Institutional Responses to Sex Trafficking in Armenia, Bosnia, and India. Kumarian Press, Sterling, VA.

DGMM (Directorate General of Migration Management).

2014 Law on Foreigners and International Protection No. 6458, http://www.goc.gov.tr/files/files/ eng_minikanun_5_son.pdf (accessed 3 March 2016).

2016 Temporary Protection Statistics, http://www.goc.gov.tr/icerik6/gecici-koruma_363_378_4713_icerik (accessed 3 March 2016)

Doezema, J.

1998 "Forced to Choose: Beyond the Voluntary v. Forced Prostitution Dichotomy", in K. Kempadoo and J. Doezema (Eds.), Global Sex Workers: Rights, Resistance and Redefinition. Routledge, London and New York: 34-50.

2000 "Loose women or lost women? The re-emergence of the myth of white slavery in contemporary discourses of trafficking in women", Gender Issues, 18(1): 23-50.

Erder, S., and S. Kaska.

2003 Irregular Migration and Trafficking in Women: The Case of Turkey, International Organization for Migration, Istanbul.

Farley, M.

2004 "'Bad for the Body, Bad for the Heart': Prostitution Harms Women Even If Legalized or Decriminalized", Violence against Women, 10(10): 1087-1125.

Gulcur, L. and P. Ilkkaracan

2002 "The "Natasha" Experience: Migrant Sex Workers from the Former Soviet Union and Eastern Europe in Turkey", Women's Studies International Forum, 25(4): 411-421.

Haberturk

2014 Neden Suriyeli Gelin? http://www.haberturk.com/gundem/haber/1003940-neden-suriyeli-gelin (accessed 3 March 2016).

Hughes, D.M.

2000 "The 'Natasha' Trade - The Transnational Shadow Market of Trafficking in Women", Journal of International Affairs, 53(2): 1-10.

Icduygu, A.

2009 "International Migration and Human Development in Turkey", Human Development Research Paper 2009/52, United Nations Development Program.

IOM (International Organization for Migration).

2008 "Migration in Turkey: A Country Profile 2008," http://publications.iom.int/bookstore/free/ Turkey_Profile2008.pdf (accessed 3 March 2016).

Isigicok, $\mathrm{O}$.

2010 "Küresel Gerçeklerle Türkiye’de Yabancı Kaçak İş̧̧i Sorunu: Boyutları ve Sonuçları", Sosyal Siyaset Konferanslarl Dergisi, 57: 435-454 (in Turkish). 
Kalfa, A.

2008 Eski Dogu Bloku Ülkeleri Kaynakli Insan Ticareti Ve Fuhus Sektöründe Çalisan Kadinlar, Master's thesis, Ankara University, Ankara (in Turkish).

Karakus, O. and E.F. McGarrell

2012 “The Distribution of Women Trafficking Market in Turkey: Does Demand Matter?", International Journal of Security and Terrorism, 3(1): 1-24.

Kaya, Y. and E. Aslan

2013 "Kadın Cinselliğinde Gelenekler ve Kültür”, Androloji Bülteni, 54(1): 214-217 (in Turkish).

Kempadoo, K.

2005 "Introduction: From moral panic to global justice: Changing perspectives on trafficking", in K. Kempadoo, J. Sanghera and B. Pattanaik (Eds.), Trafficking and Prostitution Reconsidered: New Perspectives on Migration, Sex Work, and Human Rights, Paradigm Publishers, Boulder, CO: viixxxiv.

Kirisci, K.

2007 "Border Management and EU-Turkish Relations: Convergence or Deadlock", Research Reports 2007/03, European University Institute.

Kuntay, E., and M. Cokar.

2007 Ticari Seks Medya Dosyasi, Human Resources Development Foundation, Istanbul (in Turkish).

Lobasz, J.K.

2009 "Beyond border security: Feminist approaches to human trafficking", Security Studies, 18(2): 319344.

Ministry of Foreign Affairs of the Republic of Turkey.

2015 "Turkey on Trafficking in Human Beings," http://www.mfa.gov.tr/turkey-on-trafficking-in-humanbeings.en.mfa (accessed 3 March 2016).

Ministry of Justice

1961 "Genel Kadinlar ve Genel Evlerin Tabi Olacaklari Hükümler ve Fuhus Yüzünden Bulasan Zührevi Hastaliklarla Mücadele Tüzügü”, http://www.mevzuat.gov.tr/MevzuatMetin/2.4.5984.pdf (accessed 3 March 2016).

Miriam, K.

2005 "Stopping the Traffic in Women: Power, Agency and Abolition in Feminist Debates over Sex-Trafficking”, Journal of Social Philosophy, 36(1): 1-17.

Narli, N.

2006 "Human Trafficking and Smuggling: The Process, The Actors and The Victim Profile", in Trafficking in Persons in South East Europe: A Threat to Human Security, National Defence Academy, Istanbul and Vienna: 9-37.

Outshoorn, J.

2004 The Politics of Prostitution: Women's Movements. Cambridge University Press, Cambridge, Democratic States and the Globalisation of Sex Commerce.

2005 "The Political Debates on Prostitution and Trafficking of Women", Social Politics: International Studies in Gender, State and Society, 12(1): 141-55.

Ozden, S.

2013 "Syrian Refugees in Turkey", Migration Policy Centre Report 2013/5. European University Institute, Florence.

Ozer, E.

2012 Kimse Duymaz: Türkiye’de Insan Ticareti Magdurlari Üzerine Bir Arastirma, Ayizi Kitap, Istanbul (in Turkish).

Ozturk, F. and H.N. Ardor

2007 "Suç Sanayiinin Bir Alanı İnsan Ticareti: Türkiye Açısından Bir Değerlendirme”, Ekonomik Yaklaşım, 18(62): 79-102 (in Turkish).

Passport Law

1950 Law Number 5682 of 15 July 1950, http://www.legislationline.org/documents/action/popup/id/8984 (accessed 3 March 2016).

Sever, M., O.O. Demir, and Y. Kahya

2012 Evaluation of the Identification Processes of Trafficking Victims in Turkey, International Organization for Migration, Ankara. 
Sozcu

2015 Suriyeli Kadinlara Korkunç Fuhus Tuzagi, http://www.sozcu.com.tr/2015/gunun-icinden/suriyelikadinlara-korkunc-fuhus-tuzagi-714104/ (accessed 3 March 2016).

Stoyanova, V.

2011 "Complementary protection for victims of human trafficking under the European Convention on Human Rights", Goettingen Journal of International Law, 3(2): 777-817.

$\mathrm{T} 24$

2015 Seks Isçiligi Yapan Suriyeli Kadin: Kavsakta Su Satmamiz Yasaklaninca Aç Kaldik, Çaresiz Bu Ise Basladik, http://t24.com.tr/haber/seks-isciligi-yapan-suriyeli-kadin-kavsakta-su-satmamiz-yasaklaninca-ac-kaldik-caresiz-bu-ise-basladik,305640 (accessed 3 March 2016).

Toksoz, G. and C. Unluturk-Ulutas

2012 "Is Migration Feminized? A Gender- and Ethnicity-Based Review of the Literature on Irregular Migration to Turkey", in S.P. Elitok and T. Straubhaar (Eds.), Turkey, Migration and the EU: Potentials. Challenges and Opportunities, Hamburg University Press, Hamburg: 85-112.

Toksoz, G., S. Erdogdu, and S. Kaska.

2012 Irregular Labour Migration in Turkey and Situation of Migrant Workers in the Labour Market, International Organization for Migration, Ankara.

Turk Ceza Kanunu.

2004 "Turkish Criminal Code", http://www.tbmm.gov.tr/kanunlar/k5237.html (accessed 3 March 2016).

UN (United Nations).

2000 "Protocol to Prevent, Suppress and Punish Trafficking in Persons, Especially Women and Children, Supplementing the United Nations Convention against Transnational Organized Crime", https:// treaties.un.org/doc/source/RecentTexts/18-12-a.E.doc (accessed 3 March 2016).

UNODC (United Nations Office on Drugs and Crime )

2014 Global Report on Trafficking in Persons. UN Publications, New York.

US Department of State

2015 Trafficking in Persons (TIP) Report. US Department of State, Washington, DC.

Vatandaslik Kanunu

2009 Law No. 5901, http://www.tbmm.gov.tr/kanunlar/k5901.html (accessed 3 March 2016).

Williams, F.

2010 "Migration and care: Themes, concepts and challenges", Social Policy and Society, 9(3): 385-396.

Yabancilarin Calisma Izinleri Hakkinda Kanun.

2003 Law No. 4817, http://www.mevzuat.gov.tr/MevzuatMetin/1.5.4817.pdf (accessed 3 March 2016).

Zengin, A.

2011 Iktidarin Mahremiyeti: Istanbul'da Hayat Kadinlari, Seks Isçiligi ve Siddet, Metis Yayinlari, Istanbul (in Turkish). 